\title{
ASUPAN PROTEIN YANG KURANG SEBAGAI FAKTOR RISIKO KEPADATAN TULANG RENDAH PADA WANITA PASCAMENOPAUSE
}

\author{
Dea Rizky Pradipta, Fillah Fithra Dieny ${ }^{*}$ \\ Program Studi Ilmu Gizi Fakultas Kedokteran Universitas Diponegoro \\ Jl.Dr.Sutomo No.18, Semarang, Telp (024) 8453708, Email : gizifk@ undip.ac.id
}

\begin{abstract}
Background : Postmenopausal women have an increase in bone resorption due to reduced estrogen. Inadequate protein intake on the risk of low bone mineral density. However, excessive intake of protein, especially animal protein are also at risk for low bone mineral density. This study aimed to analyze the risk of protein intake and other factors (intake of calcium, phosphorus, magnesium, zinc, age, smoking history, alcohol intake and exercise) that affect bone mineral density in postmenopausal women.

Method : Design of case-control study in postmenopausal women, the number of subjects 50 cases and 50 controls. The case group have been taken at randomized sampling, and the control group was determined by matching the nutritional status by categories of percent body fat. Data on this study include bone mineral density measured by quantitative ultrasound densitometry, percent body fat was measured by bioelectrical impedance analyzer (BIA), nutrient intake using the Food Frequency Questionnaire, smoking history, alcohol consumption, and exercise habits. Bivariate analysis using Chi-square and Fisher, multivariate analysis using logistic regression.

Result : The mean of T-score in the case group was -1.94 $\pm 0,49 S D$ and the mean of T-score in the control group was $-0.45 \pm 0,48 S D$. The mean of age in the case group $(59,34 \pm 6,88 S D)$ was higher than control group $(54,30 \pm 6,12 S D)$. The mean of intake total protein, animal protein, vegetable protein, calcium, phosphorus, magnesium and zinc in the control group were higher than the cases group. The intake of total protein, vegetable protein, zinc and age were a risk factor for bone density in postmenopausal women with OR 3,551; 2,681; 3,431 and 4,205 respectively. Animal protein intake was a protective factor for bone density in postmenopausal women with $\mathrm{OR} 0,306$. The most significant risk factors on bone mineral density in postmenopausal women were age $(O R=4,223 ; 95 \% C I=1,627-10,960)$ and total protein intake $(O R=3,566 ; 95 \% C I=1,476-8,613)$.
\end{abstract}

Conclusion : Total protein intake $<66$ gr/day had 3,551 times the risk of low bone mineral density. The age $\geq 60$ years had 4,223 times the risk of low bone mineral density.

Keyword : bone mineral density; postmenopausal; total protein intake; animal protein intake; vegetable protein intake

\section{ABSTRAK}

Latar Belakang : Wanita pascamenopause mengalami peningkatan resorpsi tulang karena berkurangnya hormon estrogen. Asupan protein yang tidak adekuat berisiko terhadap kepadatan tulang yang rendah. Namun, asupan protein yang berlebihan, terutama protein hewani juga berisiko terhadap kepadatan tulang yang rendah. Tujuan penelitian untuk menganalisis besar risiko asupan protein dan faktor lain (asupan kalsium, fosfor, magnesium, zink, usia, riwayat merokok, konsumsi alkohol dan kebiasaan olahraga) yang berpengaruh terhadap kepadatan tulang wanita pascamenopause.

Metode : Desain penelitian case-control pada wanita pascamenopause, dengan jumlah subjek 50 orang kelompok kasus dan 50 orang kelompok kontrol. Pengambilan sampel kelompok kasus dilakukan secara random sampling, dan kelompok control dengan cara matching status gizi berdasarkan kategori persen lemak tubuh. Data yang dikumpulkan meliputi kepadatan tulang yang diukur dengan densitometer Quantitative Ultrasound, persen lemak tubuh yang diukur dengan Bioelectrical Impedance Analyzer (BIA), asupan zat gizi menggunakan Food Frequency Questionnaire, riwayat merokok, konsumsi alkohol, serta kebiasaan olahraga. Analisis bivariat menggunakan Chisquare dan Fisher, analisis multivariat menggunakan uji regresi logistik.

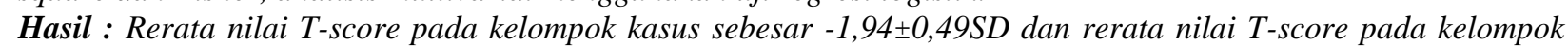
kontrol sebesar -0,45 $\pm 0,48 S D$. Rerata usia pada kelompok kasus $(59,34 \pm 6,88 S D)$ lebih tinggi daripada kelompok kontrol (54,30 $\pm 6,12 S D)$. Asupan protein total, protein hewani, protein nabati, kalsium, fosfor, magnesium dan zink pada kelompok kontrol mempunyai rerata yang lebih tinggi daripada kelompok kasus. Asupan protein total, protein nabati, zink dan usia merupakan faktor risiko kepadatan tulang pada wanita pascamenopause dengan nilai OR masing-masing sebesar 3,551; 2,681; 3,431 dan 4,205. Asupan protein hewani merupakan faktor protektif terhadap kepadatan tulang wanita pascamenopause $(O R=0,306)$. Faktor risiko yang paling berpengaruh pada kepadatan tulang wanita pascamenopause adalah usia $(O R=4,223 ; 95 \% C I=1,627-10,960)$ dan asupan protein total $(O R=3,566 ; 95 \% C I=1,476-8,613)$.

Simpulan : Asupan protein total <66 gr/hari berisiko 3,566 kali lebih besar untuk mengalami kepadatan tulang rendah. Usia $\geq 60$ tahun berisiko 4,223 kali lebih besar untuk mengalami kepadatan tulang rendah. 
Kata Kunci : kepadatan tulang; pascamenopause; asupan protein total; asupan protein hewani; asupan protein nabati

\section{PENDAHULUAN}

Angka kejadian osteoporosis cenderung meningkat dari tahun ke tahun dan terjadi hampir di seluruh negara di dunia, termasuk di Indonesia. Data dari World Health Organization (WHO) menunjukkan jumlah penduduk dunia berusia $\geq 50$ tahun yang mengalami fraktur osteoporosis terbanyak di wilayah Eropa $(34,8 \%)$ dan Asia Tenggara menempati urutan ketiga dengan jumlah 17,4\%. ${ }^{1}$ Pada tahun 2050, diperkirakan sekitar $50 \%$ kejadian patah tulang panggul terjadi di Asia. ${ }^{2}$

Usia merupakan salah satu faktor risiko terjadinya osteoporosis. Semakin bertambah usia maka akan terjadi peningkatan bone loss (pengeroposan tulang karena kehilangan mineral tulang), terutama pada lansia. ${ }^{3}$ Usia harapan hidup penduduk Indonesia adalah 72 tahun dan diprediksikan meningkat menjadi 80 tahun pada tahun $2050 .{ }^{4}$ Seiring dengan meningkatnya usia harapan hidup di negara berkembang seperti Indonesia maka terjadi peningkatan penyakit degeneratif dan metabolik, termasuk osteoporosis. ${ }^{5}$ Penelitian yang dilakukan oleh Tirtarahardja di Indonesia pada tahun 2006 menyebutkan bahwa sebanyak $23 \%$ wanita usia 50-80 tahun mengalami osteoporosis dan $53 \%$ dialami oleh wanita usia 7080 tahun. Pada tahun 2010 di Indonesia, sebanyak $71,3 \%$ dari jumlah kasus patah tulang panggul yang dirawat di rumah sakit adalah wanita yang sebagian besar berusia 61-75 tahun (46,8\%). ${ }^{6}$

Berdasarkan data Dinas Kesehatan Kota Semarang pada tahun 2012, jumlah penderita osteoporosis di Kota Semarang sebanyak 1559 orang, 1154 orang berjenis kelamin wanita dan 682 orang berusia 45-65 tahun. $^{7}$ Jumlah penderita osteoporosis terbanyak berada di wilayah kerja Puskesmas Ngemplak Simongan, yaitu sebanyak 1236 orang.

Wanita pascamenopause memiliki risiko terjadinya osteoporosis yang lebih besar dibandingkan pria atau usia yang lebih muda. Hal ini terjadi karena berkurangnya hormon estrogen setelah menopause sehingga terjadi peningkatan resorpsi tulang yang menyebabkan osteoporosis pascamenopause. Hormon estrogen pada wanita berfungsi melindungi tulang dari kehilangan massa tulang. ${ }^{8}$

Asupan protein yang rendah berisiko terhadap kepadatan tulang yang rendah karena protein sebagai penyusun struktur tulang rawan (kolagen) dan sebagai pengangkut zat gizi, termasuk kalsium. Apabila jumlah protein dalam tubuh tidak mencukupi, maka kalsium tidak dapat ditransportasikan dengan baik dan struktur tulang tidak terbentuk dengan maksimal sehingga nilai kepadatan tulang rendah. ${ }^{9}$ Penelitian yang dilakukan pada 1077 wanita berusia $\geq 75$ tahun menunjukkan hasil bahwa asupan protein yang rendah berhubungan dengan Bone Mass Density (BMD) tulang panggul yang rendah. ${ }^{10}$ Sebaliknya, asupan protein yang berlebihan, terutama protein hewani, juga berisiko terhadap kepadatan tulang yang rendah apabila tidak diimbangi dengan asupan kalsium yang cukup. $^{11}$ Penelitian menunjukkan bahwa seseorang yang mengonsumsi protein hewani lebih banyak daripada protein nabati mengalami bone loss yang lebih cepat dan mempunyai risiko patah tulang panggul yang lebih besar. Namun, beberapa penelitian tidak mendukung efek protektif protein pada bone loss maupun fraktur osteoporosis hanya pada protein nabati. ${ }^{12}$ Hal ini menunjukkan efek positif dari protein nabati pada kesehatan tulang belum konsisten.

Asupan kalsium yang rendah dapat menyebabkan osteomalasia, yaitu tulang menjadi lunak karena matriksnya kekurangan kalsium. ${ }^{13}$ Namun, asupan kalsium yang berlebihan juga tidak memberikan manfaat untuk kesehatan tulang. The Food and Drug Administration (FDA) menyebutkan bahwa asupan kalsium yang adekuat penting untuk menjaga kesehatan tulang tetapi asupan lebih dari $2000 \mathrm{mg} / \mathrm{hari}$ tidak memberikan manfaat tambahan. ${ }^{14}$

Asupan fosfor dapat mempengaruhi kepadatan tulang. Asupan fosfor yang berlebihan dalam bentuk fosfat dapat mengganggu rasio kalsium : fosfat, terutama jika asupan kalsium rendah. Hal ini mengakibatkan menurunnya konsentrasi ion kalsium dalam serum sehingga menstimulasi hormon paratiroid untuk meningkatkan aktivitas osteoklas. Jika hal ini berlangsung dalam waktu yang lama dapat mengakibatkan bone loss. ${ }^{15}$ Selain itu, kalsium dan fosfor yang membentuk kalsium fosfat dalam keadaan basa juga dapat menghambat absorpsi kalsium.

Mineral lain yang dibutuhkan dalam metabolisme tulang adalah magnesium dan zink. Asupan magnesium yang lebih tinggi berhubungan dengan kepadatan tulang yang lebih tinggi pada wanita dan pria usia lanjut. Namun penelitian dari WHI (women's health initiative) melaporkan bahwa asupan magnesium yang lebih tinggi 
berhubungan dengan risiko fraktur pergelangan tangan yang lebih tinggi. Defisiensi zink menyebabkan penurunan pertumbuhan dan maturasi tulang. Namun, hanya sedikit penelitian yang menemukan bahwa zink berperan pada massa tulang dan terjadinya fraktur osteoporosis. ${ }^{16}$

Selain faktor asupan, gaya hidup (life style) seseorang juga mempengaruhi rendahnya kepadatan tulang dan menyebabkan terjadinya osteoporosis. Kebiasaan merokok mengurangi densitas tulang karena kandungan nikotin dan kadmium dalam tembakau rokok bersifat racun terhadap osteoblas. ${ }^{17}$ Konsumsi alkohol juga berhubungan dengan rendahnya kepadatan tulang. Seseorang yang mengonsumsi alkohol secara berlebihan mempunyai massa tulang yang rendah dan berkurangnya aktivitas osteoblas sehingga meningkatkan risiko fraktur. ${ }^{14}$ Kebiasaan olahraga weight-bearing (berjalan, berlari, senam, menari, dll) secara teratur dapat meningkatkan kepadatan tulang. Pada wanita pascamenopause, berjalan dan menari berkaitan dengan lambatnya kehilangan tulang dan mengurangi risiko fraktur tulang panggul. ${ }^{17}$

Penelitian ini bertujuan untuk menganalisis asupan protein dan faktor lain (asupan kalsium, fosfor, magnesium, zink, usia, riwayat merokok, konsumsi alkohol, dan kebiasaan olahraga) sebagai faktor risiko kepadatan tulang rendah pada wanita pascamenopause.

\section{METODE PENELITIAN}

Penelitian ini merupakan penelitian observasional dengan desain case control, yang dilaksanakan pada bulan Mei-Juni 2014. Populasi dalam penelitian ini adalah wanita pascamenopause di Kota Semarang. Kriteria inklusi penelitian adalah wanita pascamenopause (tidak mengalami haid selama $\geq 1$ tahun), dapat berkomunikasi dengan baik, serta bersedia mengikuti penelitian melalui persetujuan informed consent. Kelompok kasus adalah wanita pascamenopause yang memiliki kepadatan tulang rendah, dengan nilai $T$-score $<-1 \mathrm{SD}$ sedangkan kelompok kontrol adalah wanita pascamenopause yang memiliki kepadatan tulang normal, dengan nilai $T$-score $\geq-1 \mathrm{SD}$. Total subjek dalam penelitian ini sejumlah 100 orang, terdiri dari 50 orang kelompok kasus dan 50 orang kelompok kontrol. Subjek diperoleh dari skrining pada 183 orang wanita pascamenopause di tiga kelurahan, meliputi Kelurahan Ngemplak Simongan, Kelurahan Bongsari, dan Kelurahan Barusari. Hasil skrining tersebut, sebanyak 130 orang memiliki kepadatan tulang rendah dan 53 orang memiliki kepadatan tulang normal. Subjek yang dimasukkan dalam kelompok kasus ditentukan dengan random sampling, kemudian kelompok kontrol ditentukan dengan cara matching status gizi berdasarkan kategori persen lemak tubuh. Setelah ditentukan kelompok kasus dan kontrol, subjek diberikan informed consent sebagai persetujuan menjadi subjek dalam penelitian ini, kemudian dilakukan wawancara kebiasaan makan dengan Food Frequency Questionnaire (FFQ) semi kuantitatif dan kuesioner penelitian untuk menanyakan kebiasaan olahraga, riwayat merokok dan konsumsi alkohol.

Variabel terikat dalam penelitian ini adalah kepadatan tulang wanita pascamenopause. Variabel bebas adalah asupan protein (total, hewani, nabati) dan variabel perancu adalah asupan kalsium, asupan fosfor, asupan magnesium, asupan zink, usia, riwayat merokok, konsumsi alkohol dan kebiasaan olahraga. Data yang dikumpulkan meliputi usia, lama menopause, persen lemak tubuh, kepadatan tulang, asupan zat gizi, riwayat merokok, konsumsi alkohol, dan kebiasaan olahraga. Instrumen yang digunakan dalam penelitian meliputi densitometer Quantitative Ultrasound dengan jenis mesin Achilles Insight yang dikeluarkan oleh GE (General Electric) Healthcare, Bioelectrical Impedance Analyzer (BIA) merk Tanita BC-541, formulir skrining dan kuesioner penelitian, formulir informed consent, serta formulir FFQ semi kuantitatif.

Kepadatan tulang didefinisikan sebagai nilai kepadatan tulang subjek yang diukur menggunakan densitometer Quantitative Ultrasound pada tulang calcaneus bagian tumit dan dinyatakan dengan nilai T-score. Kepadatan tulang subjek dikategorikan menjadi rendah apabila $T$-score $<-1$ SD dan normal apabila $T$-score $\geq-1$ SD. ${ }^{18}$ Persen lemak tubuh didefinisikan sebagai proporsi jaringan lemak pada tubuh, yaitu perbandingan antara massa lemak tubuh dengan massa tanpa lemak yang dinyatakan dalam persen (\%). Persen lemak tubuh dikategorikan menjadi normal $(\leq 35 \%)$ dan lebih $(>35 \%) .{ }^{19}$

Asupan zat gizi (protein total, protein hewani, protein nabati, kalsium, fosfor, magnesium, dan zink) adalah rata-rata asupan subjek dari semua bahan makanan/minuman sumber zat gizi tersebut dalam waktu satu tahun terakhir meliputi jumlah, jenis, dan frekuensi konsumsi. Data asupan diperoleh dengan formulir FFQ semi kuantitatif dan dianalisis dengan Nutrisurvey. Kategori asupan protein total adalah berisiko jika <66 gram/hari dan tidak berisiko jika 
$\geq 66$ gram $/$ hari. ${ }^{10}$ Kategori asupan protein hewani dibedakan menjadi berisiko jika $<27$ gram/hari dan tidak berisiko jika $\geq 27$ gram/hari. Kategori asupan protein nabati dibedakan menjadi berisiko jika $<36$ gram/hari dan tidak berisiko jika $\geq 36$ gram/hari. Kategori asupan protein hewani dan protein nabati diperoleh dari rata-rata konsumsi asupan protein hewani dan nabati subjek dalam penelitian ini, kemudian ditentukan jumlah asupan yang paling signifikan pada kelompok kasus dan kontrol. Kategori asupan kalsium adalah cukup apabila $\geq 1000 \mathrm{mg} /$ hari dan kurang apabila $<1000$ $\mathrm{mg} /$ hari. $^{20}$ Kategori asupan fosfor adalah cukup apabila $\geq 700 \mathrm{mg} /$ hari dan kurang apabila $<700$ $\mathrm{mg} /$ hari. ${ }^{20}$ Kategori asupan magnesium adalah cukup apabila $\geq 320 \mathrm{mg} /$ hari dan kurang apabila $<320 \mathrm{mg} /$ hari. ${ }^{20}$ Kategori asupan zink adalah cukup apabila $\geq 8 \mathrm{mg} /$ hari dan kurang apabila $<8$ $\mathrm{mg} /$ hari. $^{20}$

Riwayat merokok adalah kebiasaan merokok subjek selama satu tahun terakhir atau lebih yang diperoleh dengan wawancara langsung kepada subjek. Kategori riwayat merokok adalah "ya" apabila dalam setahun terakhir memiliki kebiasaan merokok dan "tidak" apabila dalam setahun terakhir tidak pernah merokok. Konsumsi alkohol adalah frekuensi alkohol yang dikonsumsi subjek sehari selama satu tahun terakhir atau lebih, diperoleh dengan wawancara langsung kepada subjek. Kategori konsumsi alkohol adalah "tidak" jika konsumsi alkohol $\leq 1$ kali/hari dan "ya" jika konsumsi alkohol >1 kali/hari. ${ }^{17}$ Kebiasaan olahraga adalah frekuensi olahraga pembebanan (berjalan, berlari, senam, menari) yang dilakukan oleh subjek dalam waktu seminggu selama satu tahun terakhir atau lebih, dikategorikan baik apabila subjek berolahraga $\geq 3 \mathrm{kali} /$ minggu dan kurang apabila subjek berolahraga <3 kali/minggu. ${ }^{21}$ Usia adalah lamanya waktu hidup subjek sejak dilahirkan hingga saat pengambilan data, dalam satuan tahun. Kategori usia dibedakan menjadi 46-59 tahun dan $\geq 60$ tahun. ${ }^{22}$

Analisis data menggunakan software SPSS 16.0 for Windows. Analisis univariat untuk mendeskripsikan variabel yang diteliti, meliputi usia, lama menopause, persen lemak tubuh, kepadatan tulang, asupan zat gizi, kebiasaan olahraga, riwayat merokok dan konsumsi alkohol. Analisis bivariat menggunakan Chi square dan Fisher exact. Hasil penelitian juga dianalisis dengan menentukan besar OR (odds ratio). Analisis multivariat menggunakan uji regresi logistik.

\section{HASIL PENELITIAN}

Jumlah subjek dalam penelitian ini sebanyak 100 orang, terdiri dari 50 orang kelompok kasus (kepadatan tulang rendah) dan 50 orang kelompok kontrol (kepadatan tulang normal). Tabel 1 menunjukkan gambaran umum nilai minimum, maksimum, rerata dan simpang baku untuk variabel usia, lama menopause, kepadatan tulang (nilai $T$-score), persen lemak tubuh, serta asupan zat gizi subjek pada kelompok kasus dan kontrol.

Tabel 1. Gambaran Umum Subjek

\begin{tabular}{|c|c|c|c|c|c|c|}
\hline & \multicolumn{3}{|c|}{ Kasus $(n=50)$} & \multicolumn{3}{|c|}{ Kontrol $(n=50)$} \\
\hline & Min & Maks & $\begin{array}{c}\text { Rerata } \pm \\
\text { Simpang baku }\end{array}$ & Min & Maks & $\begin{array}{c}\text { Rerata } \pm \\
\text { Simpang baku }\end{array}$ \\
\hline Usia (tahun) & 48 & 77 & $59,34 \pm 6,88$ & 46 & 72 & $54,30 \pm 6,12$ \\
\hline $\begin{array}{l}\text { Lama menopause } \\
\text { (tahun) }\end{array}$ & 1 & 27 & $10,07 \pm 7,04$ & 1 & 27 & $5,36 \pm 6,11$ \\
\hline$T$-score & $-3,1$ & $-1,1$ & $-1,94 \pm 0,49$ & $-1,0$ & 0,8 & $-0,45 \pm 0,48$ \\
\hline $\begin{array}{l}\text { Persen lemak tubuh } \\
(\%)\end{array}$ & 21,90 & 54,50 & $37,48 \pm 6,00$ & 29,60 & 49,00 & $37,51 \pm 4,10$ \\
\hline $\begin{array}{l}\text { Asupan protein total } \\
\text { (gram/hari) }\end{array}$ & 15,2 & 126,6 & $57,19 \pm 25,19$ & 33,6 & 187,5 & $78,37 \pm 35,24$ \\
\hline $\begin{array}{l}\text { Asupan protein } \\
\text { hewani (gram/hari) }\end{array}$ & 2,3 & 65 & $20,84 \pm 12,22$ & 3,8 & 110 & $30,85 \pm 19,03$ \\
\hline $\begin{array}{l}\text { Asupan protein } \\
\text { nabati (gram/hari) }\end{array}$ & 11,6 & 86,9 & $36,35 \pm 19,40$ & 16,7 & 112,1 & $47,52 \pm 21,98$ \\
\hline $\begin{array}{l}\text { Asupan kalsium } \\
\text { (mg/hari) }\end{array}$ & 87,7 & 1300,3 & $529,04 \pm 258,68$ & 209,9 & 1237,6 & $604,79 \pm 266,29$ \\
\hline $\begin{array}{l}\text { Asupan fosfor } \\
\text { (mg/hari) }\end{array}$ & 215,3 & 1900,2 & $832,99 \pm 334,13$ & 531,1 & 2351,1 & $1089,20 \pm 443,17$ \\
\hline $\begin{array}{l}\text { Asupan magnesium } \\
\text { (mg/hari) }\end{array}$ & 79,9 & 851,0 & $307,65 \pm 146,45$ & 180,9 & 890,3 & $403,14 \pm 185,38$ \\
\hline Asupan zink & 1,8 & 13,9 & $6,25 \pm 2,49$ & 3,9 & 18,2 & $8,53 \pm 3,56$ \\
\hline
\end{tabular}


(mg/hari)

Rentang usia subjek pada kedua kelompok tidak berbeda jauh, tetapi rerata usia pada kelompok kasus $(59,34 \pm 6,88 \mathrm{SD})$ lebih tinggi daripada kelompok kontrol $(54,30 \pm 6,12 \mathrm{SD})$. Lama menopause antara kedua kelompok memiliki rentang yang sama (1-27 tahun), tetapi rerata pada kelompok kasus $(10,07 \pm 7,04 \mathrm{SD})$ lebih tinggi daripada kelompok kontrol (5,36 $\pm 6,11 \mathrm{SD})$.

Rerata asupan protein total, protein hewani, protein nabati, kalsium, fosfor, magnesium, dan zink pada kelompok kontrol lebih tinggi daripada kelompok kasus. Rerata asupan protein nabati lebih tinggi daripada protein hewani, baik pada kelompok kasus maupun kelompok kontrol. Pada kelompok kasus ditemukan subjek dengan asupan kalsium maksimum sebesar 1300,3 mg/hari, lebih tinggi daripada kelompok kontrol (1237,6 $\mathrm{mg} / \mathrm{hari}$ ).

\section{Karakteristik Subjek}

Tabel 2. Distribusi Frekuensi Karakteristik Subjek

\begin{tabular}{llccccc}
\hline & & \multicolumn{2}{c}{ Kasus } & \multicolumn{2}{c}{ Kontrol } & Total \\
& & n & \% & n & \% & (n=100) \\
\hline \multirow{2}{*}{ Usia } & $46-59$ th & 26 & $52 \%$ & 41 & $82 \%$ & $67(67 \%)$ \\
& $\geq 60$ th & 24 & $48 \%$ & 9 & $18 \%$ & $33(33 \%)$ \\
\hline \multirow{2}{*}{ Lama menopause } & $1-10$ tahun & 30 & $60 \%$ & 42 & $84 \%$ & $72(72 \%)$ \\
& $>10$ tahun & 20 & $40 \%$ & 8 & $16 \%$ & $28(28 \%)$ \\
\hline \multirow{2}{*}{ Persen lemak tubuh } & Normal & 14 & $28 \%$ & 14 & $28 \%$ & $28(28 \%)$ \\
& Lebih & 36 & $72 \%$ & 36 & $72 \%$ & $72(72 \%)$ \\
\hline \multirow{2}{*}{ Kebiasaan olahraga } & Kurang & 32 & $64 \%$ & 27 & $54 \%$ & $59(59 \%)$ \\
& Baik & 18 & $36 \%$ & 23 & $46 \%$ & $41(41 \%)$ \\
\hline \multirow{2}{*}{ Riwayat merokok } & Ya & 0 & $0 \%$ & 0 & $0 \%$ & $0(0 \%)$ \\
& Tidak & 50 & $100 \%$ & 50 & $100 \%$ & $100(100 \%)$ \\
\hline \multirow{2}{*}{ Konsumsi alkohol } & Ya & 0 & $0 \%$ & 0 & $0 \%$ & $0(0 \%)$ \\
& Tidak & 50 & $100 \%$ & 50 & $100 \%$ & $100(100 \%)$ \\
\hline
\end{tabular}

Tabel 2 menunjukkan sebanyak 67\% dari keseluruhan subjek berada pada kelompok usia 4659 tahun, demikian pula dengan kelompok kontrol yang terbanyak pada kelompok usia 46-59 tahun, yaitu sebesar $82 \%$. Namun, pada kelompok kasus yang terbanyak adalah kelompok usia $\geq 60$ tahun, yaitu sebesar $48 \%$.

Subjek yang mengalami menopause lebih dari 10 tahun lebih banyak pada kelompok kasus daripada kelompok kontrol, yaitu 40\%. Pada kelompok kontrol, sebagian besar subjek mengalami menopause 1-10 tahun, yaitu $84 \%$. Pada kedua kelompok, subjek yang memiliki persen lemak tubuh normal sebanyak $28 \%$ dan persen lemak tubuh lebih sebanyak $72 \%$.

Pada kelompok kontrol, lebih banyak subjek yang mempunyai kebiasaan olahraga baik (46\%) sedangkan pada kelompok kasus lebih banyak subjek yang mempunyai kebiasaan olahraga kurang (64\%). Keseluruhan subjek pada penelitian ini, baik kelompok kasus maupun kelompok kontrol $100 \%$ tidak mempunyai riwayat merokok dan tidak mengonsumsi alkohol.

Faktor-faktor yang Berhubungan dengan Kepadatan Tulang Rendah pada Wanita Pascamenopause

Tabel 3. Hasil Analisis Bivariat Asupan Zat Gizi

\begin{tabular}{|c|c|c|c|c|c|c|c|}
\hline & \multicolumn{2}{|c|}{ Kasus } & \multicolumn{2}{|c|}{ Kontrol } & \multirow{2}{*}{$\begin{array}{c}\text { OR } \\
(95 \% \mathrm{CI})\end{array}$} & \multirow{2}{*}{$p$ value } \\
\hline & & $\mathbf{n}$ & $\%$ & $\mathbf{n}$ & $\%$ & & \\
\hline \multirow{2}{*}{$\begin{array}{l}\text { Asupan } \\
\text { protein total }\end{array}$} & $<66 \mathrm{gr}$ & 36 & $72 \%$ & 21 & $42 \%$ & $3,551^{\mathrm{a}}$ & \multirow{2}{*}{$0,002^{\mathrm{a}, \mathrm{c}}$} \\
\hline & $\geq 66 \mathrm{gr}$ & 14 & $28 \%$ & 29 & $58 \%$ & $(1,541-8,181)$ & \\
\hline \multirow{2}{*}{$\begin{array}{l}\text { Asupan } \\
\text { protein hewani }\end{array}$} & $<27 \mathrm{gr}$ & 39 & $78 \%$ & 26 & $52 \%$ & $0,306^{\mathrm{a}}$ & \multirow{2}{*}{$0,006^{\mathrm{a}, \mathrm{c}}$} \\
\hline & $\geq 27 \mathrm{gr}$ & 11 & $22 \%$ & 24 & $48 \%$ & $(0,128-0,729)$ & \\
\hline \multirow{2}{*}{$\begin{array}{l}\text { Asupan } \\
\text { protein nabati }\end{array}$} & $<36 \mathrm{gr}$ & 29 & $58 \%$ & 17 & $34 \%$ & $2,681^{\mathrm{a}}$ & \multirow{2}{*}{$0,016^{\mathrm{a}, \mathrm{c}}$} \\
\hline & $\geq 36$ gr & 21 & $42 \%$ & 33 & $66 \%$ & $(1,191-6,032)$ & \\
\hline \multirow{2}{*}{$\begin{array}{l}\text { Asupan } \\
\text { kalsium }\end{array}$} & Kurang & 49 & $98 \%$ & 45 & $90 \%$ & $5,444^{\mathrm{b}}$ & \multirow{2}{*}{$0,102^{\mathrm{b}}$} \\
\hline & Cukup & 1 & $2 \%$ & 5 & $10 \%$ & $(0,612-48,397)$ & \\
\hline \multirow{2}{*}{ Asupan fosfor } & Kurang & 15 & $30 \%$ & 12 & $24 \%$ & $1,357^{\mathrm{b}}$ & \multirow{2}{*}{$0,499^{\mathrm{a}}$} \\
\hline & Cukup & 35 & $70 \%$ & 38 & $76 \%$ & $(0,559-3,295)$ & \\
\hline
\end{tabular}




\begin{tabular}{|c|c|c|c|c|c|c|c|}
\hline \multirow{2}{*}{$\begin{array}{l}\text { Asupan } \\
\text { magnesium }\end{array}$} & Kurang & 31 & $62 \%$ & 23 & $46 \%$ & $1,915^{\mathrm{b}}$ & \multirow{2}{*}{$0,108^{a}$} \\
\hline & Cukup & 19 & $38 \%$ & 27 & $54 \%$ & $(0,863-4,250)$ & \\
\hline \multirow{2}{*}{ Asupan zink } & Kurang & 38 & $76 \%$ & 24 & $48 \%$ & $3,431^{\mathrm{a}}$ & \multirow{2}{*}{$0,004^{\mathrm{a}, \mathrm{c}}$} \\
\hline & Cukup & 12 & $24 \%$ & 26 & $52 \%$ & $(1,461-8,057)$ & \\
\hline \multirow{2}{*}{$\begin{array}{l}\text { Kebiasaan } \\
\text { olahraga }\end{array}$} & Kurang & 32 & $64 \%$ & 27 & $54 \%$ & $1,514^{\mathrm{b}}$ & \multirow{2}{*}{$0,309^{\mathrm{a}}$} \\
\hline & Baik & 18 & $36 \%$ & 23 & $46 \%$ & $(0,679-3,376)$ & \\
\hline \multirow{2}{*}{ Usia } & $46-59$ th & 26 & $52 \%$ & 41 & $82 \%$ & $4,205^{\mathrm{a}}$ & \multirow{2}{*}{$0,001^{\mathrm{a}, \mathrm{c}}$} \\
\hline & $\geq 60$ th & 24 & $48 \%$ & 9 & $18 \%$ & $(1,692-10,448)$ & \\
\hline
\end{tabular}

$p$ value : a uji Chi-square, b uji Fisher, c signifikan $\mathrm{p}<0,05$

OR : a bermakna, b tidak bermakna

Berdasarkan analisis bivariat pada tabel 3 , asupan protein total $<66$ gram/hari, asupan protein nabati <36 gram/hari, dan asupan zink yang kurang merupakan faktor risiko kepadatan tulang yang rendah pada wanita pascamenopause karena memiliki nilai $p$ yang signifikan dengan OR masing-masing sebesar 3,$551 ; 2,681$; dan 3,431 sedangkan asupan protein hewani $\geq 27$ gram/hari merupakan faktor protektif kepadatan tulang wanita pascamenopause dengan nilai OR sebesar $0,306 \quad(95 \% \mathrm{CI}=0,128-0,729)$. Usia $\geq 60$ tahun merupakan faktor risiko kepadatan tulang rendah pada wanita pascamenopause dengan nilai OR sebesar 4,205 $(95 \% \mathrm{CI}=1,692-10,448)$. Asupan kalsium, fosfor, magnesium, dan kebiasaan olahraga bukan merupakan faktor risiko kepadatan tulang rendah pada penelitian ini karena nilai $p$ tidak signifikan.

Faktor yang Paling Berpengaruh terhadap Kepadatan Tulang Rendah pada Wanita Pascamenopause

Variabel yang dimasukkan dalam analisis multivariat adalah variabel yang berdasarkan analisis bivariat mempunyai nilai $\mathrm{p}<0,25$ yaitu asupan protein total, asupan protein hewani, asupan protein nabati, asupan kalsium, asupan magnesium, asupan zink dan usia. Hasil analisis multivariat dengan uji regresi logistik dapat dilihat pada tabel 4 berikut ini.

Tabel 4. Hasil Analisis Multivariat Regresi Logistik

\begin{tabular}{|c|c|c|c|c|}
\hline Variabel & Koefisien & p value & OR & $95 \% \mathrm{CI}$ \\
\hline Usia & 1,440 & $0,003^{a}$ & $4,223^{\mathrm{a}}$ & $1,627-10,960$ \\
\hline Asupan protein total & 1,271 & $0,005^{\mathrm{a}}$ & $3,566^{\mathrm{a}}$ & $1,476-8,613$ \\
\hline Konstanta & $-1,187$ & $0,002^{\mathrm{a}}$ & 0,305 & - \\
\hline
\end{tabular}

$p$ value : a signifikan $\mathrm{p}<0,05, \mathrm{~b}$ tidak signifikan

OR : a bermakna, $\mathrm{b}$ tidak bermakna

Hasil uji regresi logistik pada tabel 4 menunjukkan bahwa faktor risiko yang paling berpengaruh pada kepadatan tulang wanita pascamenopause adalah usia dan asupan protein total, dengan nilai OR masing-masing sebesar $4,223 \quad(95 \% \mathrm{CI}=1,627-10,960)$ dan 3,566 $(95 \% \mathrm{CI}=1,476-8,613)$. Nilai OR sebesar 4,223 menunjukkan bahwa seseorang yang berusia $\geq 60$ tahun berisiko 4,223 kali lebih besar untuk mengalami kepadatan tulang rendah. Nilai OR sebesar 3,566 menunjukkan bahwa seseorang yang mengonsumsi protein total $<66$ gram/hari berisiko 3,566 kali lebih besar untuk mengalami kepadatan tulang rendah.

Persamaan yang didapatkan dari hasil regresi logistik tersebut untuk memprediksi kepadatan tulang rendah adalah $\mathrm{y}=-1,187+$ 1,440 (usia $\geq 60$ tahun) $+1,271$ (asupan protein total $<66$ gram/hari). Interpretasi dari persamaan tersebut adalah setiap peningkatan asupan protein sebanyak 1 gram/hari maka akan meningkatkan kepadatan tulang sebesar 1,271SD. Jika asupan protein total $<66$ gram/hari dan usia $\geq 60$ tahun, maka kemungkinan (probabilitas) subjek penelitian akan mengalami kepadatan tulang rendah sebesar $82 \%$.

\section{PEMBAHASAN \\ Karakteristik Subjek}

Hasil penelitian ini menunjukkan rerata usia subjek pada kedua kelompok adalah $>50$ tahun dan rerata kelompok kasus lebih tinggi daripada kelompok kontrol. Rerata usia pada kelompok kasus $(59,34 \pm 6,88 \mathrm{SD})$ dan kelompok kontrol $(54,30 \pm 6,12 \mathrm{SD})$ hampir sama dengan penelitian cross sectional pada wanita pascamenopause di Tasikmalaya tahun 2006 yang menunjukkan bahwa rerata usia responden adalah $56 \pm 7,9 \mathrm{SD} .{ }^{23}$ Hasil penelitian juga sesuai dengan teori bahwa wanita berusia 50 tahun mempunyai peluang untuk menderita osteoporosis sebesar 50\%, kemudian setelah wanita berusia lebih dari 50 tahun akan 
mengalami percepatan bone loss. Studi yang dilakukan pada 200.000 wanita berusia $\geq 50$ tahun dengan mengukur nilai BMD dan dibandingkan dengan standar WHO menunjukkan bahwa $40 \%$ menderita osteopenia (1-2,5 SD di bawah nilai normal) dan sebanyak $7 \%$ menderita osteoporosis. ${ }^{15}$

Usia akan mempengaruhi kepadatan tulang seseorang. Peningkatan bone loss terjadi seiring dengan pertambahan usia, terutama pada lansia. Kehilangan massa tulang yang terjadi pada wanita pascamenopause sebesar $0,5-1 \%$ per tahun dari berat tulang. ${ }^{3}$ Semakin tua usia seseorang, terutama pada masa pascamenopause, kehilangan massa tulang progresif terjadi sebagai akibat penggantian atau pengisian tulang yang tidak lengkap setelah diresorpsi. $^{24}$ World Health Organization mengelompokkan usia 46-59 tahun ke dalam kategori middle age (usia pertengahan) dan $\geq 60$ tahun termasuk kategori elderly (lansia). ${ }^{22}$ Hasil penelitian ini menunjukkan bahwa subjek yang berusia $\geq 60$ tahun lebih banyak ditemukan pada kelompok kasus daripada kelompok kontrol. Secara teori, wanita pascamenopause akan memasuki range risiko fraktur setelah usia 60 tahun karena pada usia di atas 60 tahun terjadi abnormalitas bone turnover (proses penyerapan tulang lebih banyak terjadi daripada pembentukan tulang) sehingga risiko osteoporosis dan fraktur meningkat. ${ }^{15}$ Wanita pascamenopause juga akan mengalami penurunan tinggi badan hingga $20 \mathrm{~cm}$ antara usia 50-80 tahun, menimbulkan gambaran khas dowager hump (wanita tua yang bungkuk). ${ }^{8}$

Pada tabel 2 dapat dilihat bahwa sebanyak $40 \%$ subjek pada kelompok kasus mengalami menopause selama $>10$ tahun. Hal ini menunjukkan bahwa semakin lama seseorang mengalami menopause maka kepadatan tulang cenderung rendah. Hal ini berkaitan dengan berkurangnya hormon estrogen pada masa menopause. Defisiensi hormon estrogen pada masa menopause mengakibatkan terjadinya resorpsi tulang yang berlebihan dan menghambat proses pengisian pada rongga resorpsi sehingga tulang trabekular mengalami penipisan. Hal ini menjadikan struktur tulang trabekular lemah sehingga lebih mudah fraktur. ${ }^{24}$

Olahraga secara teratur, terutama olahraga pembebanan (weight-bearing) seperti berjalan, berlari, senam, dan menari dapat meningkatkan massa tulang dengan meningkatkan massa otot yang memberikan pembebanan pada tulang sehingga kepadatan tulang meningkat. Hasil penelitian pada tabel 2 menunjukkan bahwa sebagian besar subjek memiliki kebiasaan olahraga yang kurang pada kelompok kasus dan kontrol. Kebiasaan olahraga yang kurang dapat meningkatkan risiko osteoporosis. Hal ini seperti penelitian yang dilakukan pada wanita lansia di Bogor menunjukkan bahwa sebagian besar subjek jarang melakukan kegiatan olahraga sehingga aktivitas fisiknya tergolong ringan atau kurang, dan berisiko mengalami osteoporosis 8 kali lebih besar. ${ }^{25}$ Studi kohort pada lebih dari 61.000 wanita pascamenopause menunjukkan bahwa mereka yang berjalan sedikitnya empat jam setiap minggu mempunyai $41 \%$ risiko fraktur yang lebih rendah daripada mereka yang berjalan kurang dari satu jam setiap minggu. ${ }^{17}$

Olahraga memberikan beban mekanis pada tulang. Adanya pembebanan mekanik pada tulang (skeletal load) menimbulkan stress mekanik dan strain (resultant tissue deformation). Hal ini mengakibatkan terjadinya pembentukan tulang pada permukaan periostal dan berkurangnya penyerapan tulang sehingga memperkuat tulang. ${ }^{26}$ Olahraga (tegangan) dapat meningkatkan jumlah sel osteoblas dan menurunkan jumlah sel osteoklas melalui mekanisme mekanotransduksi. Tegangan yang dihasilkan olahraga akan menginduksi produksi nitrit oksida (NO), yang menekan aktivitas osteoklas dan meningkatkan aktivitas osteoblas. Tegangan ini juga menginduksi sintesis prostaglandin dengan cara meningkatkan aktivitas siklooksigenase. Prostaglandin kemudian akan menstimulasi aktivitas osteoblas melalui insulin growth factor, yang meningkat pada awal stimulasi mekanis (olahraga). Olahraga yang paling sederhana adalah berjalan kaki selama 30-60 menit sehari. $^{27}$

Gangguan remodeling tulang pada masa menopause menyebabkan bone turnover yang cepat dan mempercepat hilangnya mineral-mineral tulang. Olahraga pembebanan perlu dilakukan untuk memberikan stress mekanik pada tulang rangka, latihan ini efektif untuk mencegah kehilangan massa tulang karena penuaan. Olahraga pembebanan seperti berjalan, jogging, bermain tenis atau menaiki tangga akan menghasilkan strain mekanik yang cukup bagi wanita pascamenopause sehat. $^{28}$

\section{Faktor-faktor yang Berhubungan dengan Kepadatan Tulang Rendah pada Wanita Pascamenopause}

Hasil penelitian pada tabel 1 menunjukkan bahwa rerata asupan protein total, protein hewani dan protein nabati pada kelompok kontrol lebih tinggi daripada kelompok kasus. Hasil yang sama ditunjukkan pada penelitian case control di Spanyol pada subjek berusia $\geq 65$ tahun, yaitu 
rerata asupan protein total, protein hewani dan protein nabati pada kelompok kontrol lebih tinggi daripada kelompok kasus. Dalam penelitian tersebut, asupan protein hewani merupakan faktor protektif terhadap fraktur osteoporosis pada lansia. $^{29}$ Berdasarkan analisis bivariat yang disajikan pada tabel 3 menunjukkan bahwa asupan protein total, protein nabati, dan zink yang kurang merupakan faktor risiko kepadatan tulang rendah pada wanita pascamenopause.

Hasil penelitian ini sesuai dengan teori bahwa asupan protein esensial untuk pembentukan matriks organik tulang dan dibutuhkan untuk menjaga produksi hormon yang berperan untuk sintesis tulang. Rendahnya asupan protein pada lansia berhubungan dengan risiko fraktur osteoporosis. ${ }^{17}$ Asupan protein yang adekuat dapat meningkatkan serum insulin growth factor (IGF1), yang berfungsi untuk menstimulasi proliferasi dan diferensiasi sel osteoblas, serta meningkatkan sintesis kolagen dan matriks tulang. ${ }^{30}$ Asupan protein normal untuk orang dewasa sekitar 1 gram $/ \mathrm{kgBB} /$ hari untuk menjaga konsentrasi serum PTH (hormon paratiroid) dalam batas normal, jika asupan kalsium juga sesuai dengan yang dianjurkan. ${ }^{15}$ Hasil penelitian ini juga sejalan dengan studi populasi yang dilakukan oleh Framingham Osteoporosis Study bahwa asupan protein yang rendah pada lansia (wanita dan pria berusia 68-91 tahun) berhubungan dengan BMD loss, sementara asupan protein yang lebih tinggi berhubungan dengan penurunan bone loss atau untuk menjaga kepadatan tulang. Studi populasi ini mendukung bahwa asupan protein yang adekuat penting untuk menjaga kesehatan tulang pada usia tua. ${ }^{31}$

Protein hewani mengandung asam amino sistein dan metionin yang mengandung sulfur. Asupan yang berlebihan menyebabkan keadaan darah dalam tubuh menjadi lebih asam sehingga untuk menetralkannya diperlukan kalsium bikarbonat yang bersifat basa. Apabila jumlah kalsium dalam darah tidak mencukupi, maka tubuh akan mengambil cadangan kalsium di tulang. Jika hal ini berlangsung dalam waktu yang lama maka kepadatan tulang akan menurun. ${ }^{14}$ Hasil penelitian ini menunjukkan bahwa asupan protein hewani merupakan faktor protektif kepadatan tulang wanita pascamenopause $(\mathrm{OR}=0,306)$, dimana subjek yang mengonsumsi protein hewani $\geq 27$ gram (setara dengan 4 penukar lauk hewani) lebih banyak ditemukan pada kelompok kontrol. Efek protektif protein hewani terhadap kepadatan tulang dapat terjadi karena protein hewani mengandung asam amino leusin yang berperan dalam sintesis protein otot, yang dapat meningkatkan kekuatan dan kepadatan tulang. ${ }^{32}$ Beberapa penelitian menunjukkan bahwa asupan protein hewani yang tinggi berhubungan positif dengan kepadatan tulang dan penurunan risiko fraktur pada wanita pascamenopause. Penelitian case-control yang dilakukan pada lansia berusia $\geq 65$ tahun $(80 \%$ adalah wanita) menunjukkan hasil bahwa asupan protein hewani yang lebih tinggi pada kelompok kontrol memungkinkan efek protektif fraktur osteoporosis pada lansia. ${ }^{29}$ Protein hewani (terutama daging dan susu) mengandung kalium dalam jumlah yang cukup tinggi, berkontribusi sebagai prekursor bikarbonat yang diperlukan untuk keseimbangan asam basa. ${ }^{12}$

Asupan protein nabati yang kurang dalam penelitian ini menjadi faktor risiko kepadatan tulang rendah pada wanita pascamenopause. Hasil penelitian ini mendukung hasil studi populasi kohort yang menyatakan bahwa asupan protein nabati mempunyai peran penting untuk menjaga kesehatan tulang. ${ }^{33}$ Protein nabati mempunyai efek yang berlawanan dengan protein hewani. Katabolisme protein nabati menghasilkan asam yang lebih sedikit dan karena alkalinitasnya maka kurang mempunyai efek yang merugikan. ${ }^{30}$ Diet buah-buahan, sayuran serta protein nabati yang cukup, akan menghasilkan lingkungan yang lebih basa dalam tubuh sehingga tidak mengharuskan pengambilan kalsium dari tulang untuk mempertahankan keseimbangan asam basa. Penelitian menunjukkan bahwa diet yang mengandung buah-buahan, sayuran dan protein nabati berhubungan dengan kepadatan tulang yang lebih tinggi. ${ }^{17}$

Hasil penelitian menunjukkan asupan zink yang kurang dari yang dianjurkan $(<8 \mathrm{mg} /$ hari $)$ merupakan faktor risiko kepadatan tulang yang rendah pada wanita pascamenopause. Hal ini sesuai dengan teori bahwa asupan zink berperan dalam kesehatan tulang. Zink dibutuhkan untuk aktivitas osteoblas dengan mengaktivasi aminoacyl-tRNA synthetase pada sel osteoblas dan menstimulasi sintesis protein seluler. Zink juga berperan dalam proses mineralisasi tulang, sebagai kofaktor enzim alkaline phosphatase. ${ }^{34}$ Kekurangan zink diusulkan sebagai faktor risiko osteoporosis, terutama karena banyak lansia yang mengonsumsi makanan yang mengandung sedikit zink. Beberapa penelitian melaporkan bahwa wanita yang mengalami osteoporosis pascamenopause terjadi peningkatan level zink pada urin dibandingkan dengan kelompok kontrol yang sehat, dan di populasi, ekskresi zink dalam urin berhubungan dengan resorpsi tulang. 
Suplementasi zink dilaporkan dapat mengurangi kehilangan tulang (bone loss), tetapi suplemen tersebut mengandung elemen lain seperti kalsium. ${ }^{35}$ Hasil penelitian menunjukkan bahwa asupan zink yang berhubungan dengan peningkatan BMD pada wanita pascamenopause adalah lebih tinggi $(15 \mathrm{mg} / \mathrm{hari})$ daripada RDA (8 $\mathrm{mg} /$ hari). ${ }^{36}$

Hasil penelitian menunjukkan bahwa asupan kalsium, fosfor dan magnesium yang kurang bukan merupakan faktor risiko kepadatan tulang rendah pada wanita pascamenopause. Hal ini disebabkan kalsium, fosfor, dan magnesium terdapat dalam jumlah kecil dalam makanan dan pada usia tua kemampuan absorpsi seseorang akan menurun sehingga hanya sedikit jumlah kalsium, fosfor dan magnesium yang dapat terabsorpsi. ${ }^{14}$ Asupan kalsium yang cukup pada wanita pascamenopause dibutuhkan untuk mencegah pengambilan cadangan kalsium yang berlebihan dalam matriks tulang serta menekan produksi hormon paratiroid (PTH) sehingga dapat mengurangi risiko osteoporosis. $^{8,15,17}$ Hasil penelitian menunjukkan bahwa sebagian besar subjek pada kedua kelompok mengonsumsi kalsium dalam jumlah kurang karena banyak yang tidak mengonsumsi susu dengan alasan tidak mampu membeli atau tidak suka bau susu yang amis, padahal susu mengandung kalsium yang cukup besar (sekitar 200-400 mg/cup). ${ }^{14}$ Asupan fosfor subjek dalam penelitian ini sebagian besar berasal dari bahan nabati yang mempunyai bioavailabilitas lebih rendah sehingga hanya sedikit yang terabsorpsi. Padahal secara teori, kepadatan tulang yang rendah berhubungan dengan asupan fosfor yang berlebihan. ${ }^{8,15}$

Kebiasaan olahraga bukan merupakan faktor risiko kepadatan tulang rendah dalam penelitian ini. Secara teori, olahraga yang teratur terutama jenis olahraga pembebanan (weight-bearing) yang dilakukan minimal tiga kali seminggu dapat meningkatkan massa tulang serta menurunkan demineralisasi tulang. Beberapa studi cross sectional menunjukkan efek yang menguntungkan dari weight-bearing exercise terhadap puncak massa tulang. ${ }^{37}$ Hubungan kebiasaan olahraga dengan kepadatan tulang dipengaruhi oleh asupan kalsium, kebiasaan olahraga akan memberikan efek positif pada kepadatan tulang jika diimbangi dengan asupan kalsium yang cukup $(\geq 1000$ $\mathrm{mg} /$ hari). Sebaliknya, asupan kalsium yang cukup tidak akan membantu pembentukan tulang yang maksimal jika tidak disertai dengan olahraga yang teratur. ${ }^{38}$ Dalam penelitian ini, sebagian besar subjek memiliki kebiasaan olahraga yang kurang dan asupan kalsium juga dalam kategori kurang, sehingga tidak memberikan efek positif terhadap kepadatan tulang wanita pascamenopause.

Faktor yang Paling Berpengaruh terhadap Kepadatan Tulang Rendah pada Wanita Pascamenopause

Berdasarkan analisis multivariat, diketahui bahwa variabel usia dan asupan protein total merupakan faktor risiko yang paling berpengaruh terhadap kepadatan tulang wanita pascamenopause. Asupan protein <66 gram/hari (0,8-1 gr/kgBB/hari) sebagai faktor risiko kepadatan tulang rendah pada wanita pascamenopause $(\mathrm{OR}=3,566)$. Hasil penelitian ini sejalan dengan penelitian cross sectional pada 1077 wanita berusia $75 \pm 3$ tahun yang menyebutkan bahwa seseorang yang mengonsumsi diet rendah protein mempunyai kepadatan tulang yang rendah, dimana asupan protein yang signifikan terhadap kepadatan tulang yang rendah adalah <66 gram/hari. Penelitian tersebut mendukung teori bahwa asupan protein mempunyai efek yang menguntungkan untuk massa tulang. Asupan protein $>66$ gram/hari $(0,84$ $\mathrm{gr} / \mathrm{kgBB} / \mathrm{hari}$ ) dibutuhkan oleh lansia wanita untuk memaksimalkan massa tulang. ${ }^{10}$ Studi case control juga menunjukkan bahwa asupan protein yang lebih besar berhubungan dengan penurunan risiko fraktur tulang panggul pada pria dan wanita berusia 50-69 tahun. ${ }^{36}$ Usia $\geq 60$ tahun sebagai faktor risiko kepadatan tulang rendah pada wanita pascamenopause memiliki nilai OR yang paling besar yaitu 4,223. Hal ini menunjukkan bahwa faktor usia memang sangat berpengaruh terhadap kepadatan tulang. Seiring pertambahan usia, secara alami akan terjadi peningkatan bone loss, dan pada wanita pascamenopause akan kehilangan massa tulang sebesar $0,5-1 \%$ per tahun dari berat tulang. ${ }^{3}$ Proses kehilangan massa tulang mengalami percepatan hingga $2-3 \%$ per tahun selama periode 5-10 tahun setelah menopause dan menurun kembali menjadi $0,5-1 \%$ per tahun setelahnya. ${ }^{15}$

Asupan zink menjadi tidak bermakna pada analisis multivariat karena asupan zink bukan merupakan faktor satu-satunya yang menyebabkan kepadatan tulang rendah pada wanita pascamenopause, masih ada faktor asupan kalsium dan magnesium yang dapat mempengaruhi absorpsi zink karena ketiganya mempunyai kation divalen sehingga saling berkompetisi untuk diabsorpsi. ${ }^{14}$ Demikian halnya dengan asupan protein hewani dan protein nabati yang tidak bermakna pada analisis multivariat karena keduanya dibutuhkan dalam jumlah cukup untuk mendukung asupan protein total yang adekuat 
untuk memaksimalkan absorpsi kalsium dan menyusun matriks organik tulang. ${ }^{15}$ Secara teori, protein bersifat amfoter (dapat bereaksi dengan asam dan basa) sehingga berfungsi sebagai buffer untuk menjaga keseimbangan asam basa dalam tubuh. Ketika protein dari sumber hewani dikonsumsi secara berlebihan maka menyebabkan keadaan darah menjadi lebih asam ( $\mathrm{pH}$ rendah). Jika asupan protein nabati cukup maka dapat mengimbangi kelebihan asam yang dihasilkan dari katabolisme protein hewani, yaitu gugus amino $\left(\mathrm{NH}_{2}\right)$ atau gugus basa dalam protein nabati akan berikatan dengan hidrogen $\left(\mathrm{H}^{+}\right)$sehingga protein bermuatan positif, menyebabkan $\mathrm{pH}$ meningkat dan keseimbangan $\mathrm{pH}$ terjadi. ${ }^{9}, 39$

\section{SIMPULAN}

Asupan protein total, protein nabati, dan zink yang kurang serta usia $\geq 60$ tahun merupakan faktor risiko kepadatan tulang rendah pada wanita pascamenopause sedangkan asupan kalsium, fosfor, magnesium, dan kebiasaan olahraga bukan merupakan faktor risiko kepadatan tulang rendah pada wanita pascamenopause dalam penelitian ini. Asupan protein hewani $\geq 27$ gram/hari merupakan faktor protektif kepadatan tulang wanita pascamenopause $(\mathrm{OR}=0,306)$. Usia $\geq 60$ tahun dan asupan protein total $<66$ gram/hari merupakan faktor risiko yang paling signifikan terhadap kepadatan tulang wanita pascamenopause. Subjek yang berusia $\geq 60$ tahun berisiko 4,223 kali lebih besar untuk mengalami kepadatan tulang rendah dan subjek yang mengonsumsi protein total $<66$ gram/hari berisiko 3,566 kali lebih besar untuk mengalami kepadatan tulang rendah.

\section{SARAN}

Asupan protein yang cukup (0,8-1 $\mathrm{gr} / \mathrm{kgBB} / \mathrm{hari}$ ) dianjurkan untuk menjaga kepadatan tulang wanita pascamenopause. Asupan protein dari sumber hewani dan nabati yang seimbang diperlukan agar tidak menimbulkan efek negatif terhadap kepadatan tulang. Faktor lain seperti asupan kalsium, fosfor, magnesium, dan zink yang cukup disertai dengan kebiasaan olahraga yang teratur (30 menit/hari, minimal tiga kali seminggu) perlu diperhatikan agar tidak mengalami mengalami kepadatan tulang rendah yang dapat meningkatkan risiko osteoporosis pada wanita pascamenopause.

\section{DAFTAR PUSTAKA}

1. World Health Organization. Summary Meeting Report : WHO Scientific Group on the Assessment of Osteoporosis at Primary Health Care Level. 2004; p.2.

2. The Asia-Pacific Regional Audit; Epidemiology, Costs and Burden of Osteoporosis in 2013. International Osteoporosis Foundation. 2013; p.11.

3. Martono H. Penyakit Tulang dan Patah Tulang. Dalam : Buku Ajar Boedhi Darmojo Geriatri (Ilmu Kesehatan Usia Lanjut). Jakarta : Balai Penerbit FK UI. 2009; hlm.261-272.

4. Mithal A, Ebeling P, Kyer CS. The Asia-Pacific Regional Audit : Epidemiology, Costs and Burden of Osteoporosis in 2013. International Osteoporosis Foundation. 2013; p.56-60.

5. Setiyohadi B. Osteoporosis. Dalam : Buku Ajar Ilmu Penyakit Dalam Jilid II Edisi IV. Departemen Ilmu Penyakit Dalam, Fakultas Kedokteran Universitas Indonesia. Jakarta. 2007; hlm.12591274.

6. Tirtarahardja G, Setyohadi B, Weynand LS, Zhou Q. Bone Mineral Density Reference Values for Indonesian Men and Women. In : The Asia-Pacific Regional Audit; Epidemiology, Costs and Burden of Osteoporosis in 2013. International Osteoporosis Foundation. 2013.

7. Dinas Kesehatan Kota Semarang. Profil Kesehatan Kota Semarang tahun 2012.

8. Harvey N, Cooper C. Pencegahan Penyakit : Osteoporosis dan Fraktur Panggul. Dalam : Gizi Kesehatan Masyarakat. Jakarta : Penerbit Buku Kedokteran EGC; 2009.

9. Winarno FG. Kimia Pangan dan Gizi. Jakarta : Gramedia Pustaka Utama. 2004; hlm.50-83.

10. Devine A, Dick IM, Islam AFM, Dhaliwal SS, Prince RL. Protein Consumption is An Important Predictor of Lower Limb Bone Mass in Elderly Women. Am J Clin Nutr. 2005; 81:1423-8.

11. Sahni S, Cupples LA, Mclean RR, Tucker KL, Broe KE, Kiel DP, et al. Protective Effect of High Protein and Calcium Intake on the Risk of Hip Fracture in the Framingham Offspring Cohort. Journal of Bone and Mineral Research. 2010; vol.25 (12): 2770-2776.

12. Bonjour JP. Dietary Protein : An Essential Nutrient for Bone Health. Journal of the American College of Nutrition 2005: 24 (6); 526S-536S.

13. Winarno FG. Kimia Pangan dan Gizi. Jakarta : Gramedia Pustaka Utama. 2004; hlm.150-170.

14. Gropper SS, Smith JL, Groff JL. Advanced Nutrition and Human Metabolism. $5^{\text {th }}$ ed. Australia : Wadsworth. 2009; p.429-467.

15. Anderson, JJB. Nutrition and Bone Health. In: Mahan LK, Escott-Stump S. Krause's Food and Nutrition Therapy. 12 ed. 2008; p. 614-635.

16. Nieves JW. Osteoporosis : the role of micronutrients. Am J Clin Nutr 2005; 81 (suppl):1232S-9S.

17. Lee RD. Diseases of the Musculoskeletal System. In: Nutrition Therapy and Pathophysiology. $2^{\text {nd }}$ edition. 2010; p.771-787. 
18. National Osteoporosis Foundation. Clinician's Guide to Prevention and Treatment of Osteoporosis. 2014; p.19.

19. Whitney E, Rolfes SR. Understanding Nutrition. 12 ed. Australia : Wadsworth. 2011; p.254.

20. Dietary Reference Intake. 2010. Available at http://www.nap.edu.

21. Meikawati W, Amalia R. Hubungan Kebiasaan Minum Susu dan Olahraga dengan Kepadatan Tulang Remaja (Studi di SMAN 3 Semarang). Prosiding Seminar Nasional UNIMUS 2010. Available at : http://jurnal.unimus.ac.id.

22. World Health Organization. Definition of an Older and Elderly Person. Available at : http://www.who.int/healthinfo/survey/ageingdefno lder/en/

23. Kosnayani AS. Hubungan Asupan Kalsium, Aktivitas Fisik, Paritas, Indeks Massa Tubuh dan Kepadatan Tulang pada Wanita Pascamenopause [Tesis]. Universitas Diponegoro. 2007.

24. Pettifor JM, Prentice A, Ward K, Jones PC. The Skeletal System. In : Nutrition and Metabolism. $2^{\text {nd }}$ ed. The Nutrition Society. 2011; p.272-311.

25. Marjan AQ, Narliyati SA. Hubungan antara Pola Konsumsi Pangan dan Aktivitas Fisik dengan Kejadian Osteoporosis pada Lansia di Panti Werdha Bogor. Jurnal Gizi dan Pangan. 2013; 8(2):123-128

26. Kawiyana IKS. Osteoporosis Patogenesis Diagnosis dan Penanganan Terkini. Jurnal Penyakit Dalam. 2009; 10(2):157-170.

27. Yuliana. Peran Mekanotransduksi dalam Patofisiologi Osteoporosis. Jurnal Ilmiah Kedokteran Medicina. 2012; 43(3):191-195

28. Alev A, Merih Y. Influence of Aquatic and Weight-Bearing Exercises on Quantitative Ultrasound Variables in Postmenopausal Women. American Journal of Physical Medicine \& Rehabilitation. 2005; 84(1):52-61

29. Martínez-Ramírez MJ, Delgado-Martínez AD, Ruiz-Bailén M, Fuente C, Martínez-González MA, Delgado-Rodríguez M. Protein intake and fracture risk in elderly people : a case-control study. Elsevier Ltd and European Society for Clinical Nutrition and Metabolism. 2011.

30. Barker ME and Blumsohn A. Nutrition and the Skeleton. In : Human Nutrition. $11^{\text {th }}$ ed. Elsevier. 2005; p. 443-460.

31. Hannan MT, Tucker KL, Dawson-Hughes B, Cupples LA, Felson DT and Kiel DP. Effect of Dietary Protein on Bone Loss in Elderly Men and Women : The Framingham Osteoporosis Study. Journal of Bone Mineral Research. 2000.

32. Cao JJ, Nielsen FH. Acid diet (high-meat protein) effects on calcium metabolism and bone health. Curr Opin Clin Nutr Metab Care. 2010; 13:698702.

33. Weikert C, Walter D, Hoffmann K, Kroke A, Bergmann $\mathrm{MM}$, and Boeing $\mathrm{H}$. The Relation between Dietary Protein, Calcium and Bone
Health in Women: Results from the EPIC-Postdam Cohort. Ann Nutr Metab. 2005; 49:312-318.

34. Meunier N, O'Connor JM, Maiani G, Cashman KD, Secker DL, Ferry M, et al. Importance of Zinc in the Elderly: the ZENITH Study. European Journal of Clinical Nutrition. 2005.

35. Palacios C. The Role of Nutrients in Bone Health, from A to Z. Critical Reviews in Food Science and Nutrition 2006; 46:621-628.

36. Wengreen HJ, Munger RG, Cutler DR, Corcoran CD, Zhang J, Sassano NE. Dietary Protein Intake and Risk of Hip Fracture in Elderly Residents of Utah. J Bone Miner Res. 2004; 19:537-45.

37. Ryder KM, Shorr RI, Bush AJ, Kritchevsky SB, Harris T, Stone K, et al. Magnesium Intake from Food and Supplements is Associated with Bone Mineral Density in Healthy Older White Subjects. Journal of American Geriatrics Society 2005; 53:1875-1880.

38. IFIC Review : Physical Activity, Nutrition, and Bone Health. International Food Information Council Foundation. Available at : http://www.foodinsight.org/Content/76/BoneHealt hIFICReview.pdf

39. Gropper SS, Smith JL, Groff JL. Advanced Nutrition and Human Metabolism. $5^{\text {th }}$ ed. Australia : Wadsworth. 2009; p.179-249. 